\title{
Japan's Investment Trust: A Vehicle of Savings for Tomorrow \\ Noboru Tanabe*
}

\section{INTRODUCTION}

Japan's investment trusts have experienced phenomenal growth over the past decade. From 1979 to 1989 , the total net assets of Japan's investment trusts grew from 6 trillion yen to 58.6 trillion yen, an almost tenfold increase. ${ }^{1}$ During this same period, the total net assets of the United States' mutual funds industry also increased at a tenfold rate from 94.5 billion dollars to 982 billion dollars. ${ }^{2}$ If Japan's investment

- Mr. Tanabe is the Chairman of the Board of Counselors, Japan Investment Trust System Research Institute. After graduating from Hitotsubashi University, Mr. Tanabe began his career with Japan's Ministry of Finance and held various key posts in Banking, Securities \& Exchange and Taxation Departments. In 1962-63, Mr. Tanabe participated in the International Tax Program at Harvard Law School. From 1964 to 1967, Mr. Tanabe worked for the. Fiscal Affairs Department of the International Monetary Fund. In 1990, Mr. Tanabe returned to Harvard Law School as a Visiting Scholar to engage in research on investment trusts from an international perspective.

Mr. Tanabe thanks the following persons for their valuable support and advice in reviewing earlier drafts of this manuscript: Professors Oliver Oldman and Howell Jackson of Harvard Law School, Robert Pozen of Fidelity Investments, Vito Tanzi of the International Monetary Fund, and John Tesoro of Arthur Anderson \& Co. Financial support for Mr. Tanabe's research was provided by the Harvard Law School Pacific Community Legal Research Program, Nomura Securities Investment Trust Management Co., and Arthur Andersen \& Co. Major research assistance on this paper was provided by Timothy Church, and additional research was provided by Atsuko Hirose both Harvard Law School students of the J.D. class of 1993.

1. Investment Trusts Association of Japan, Monthly Survey of Securities Investment Trusts (Dec. 1990).

Japanese Investment Trusts:

(Total Net Assets in Billions of Yen with \% in Parenthesis)

(1) Stocks

December 1979

(2) Warrants

(3) Bonds

(4) Call Loans

(5) Others TOTAL

$1,840(30.6)$
-
$3,096(51.4)$
$1,047(17.4)$
$\frac{39(.06)}{6,022}$

December 1984

$2,764(15.1)$

$$
13,465(73.6)
$$$$
2,145(11.7)
$$$$
\frac{-76(-0.4)}{18,298}
$$

December 1989

22,533 (38.4)

$17,845(30.4)$

$18,314(31.2)$

$\frac{-222(-0.3)}{58,649}$

Call loans include bills bought, commercial paper, and certificates of deposit.

2. U.S. Investment Company Institute, Mutual Fund Fact Book 1990, 78 (1990). 
trusts are to continue this vigorous expansion, there must be a deeper understanding of the uniqueness of Japan's investment trust, which is the result of many efforts to develop an investment product with a strong savings orientation. This Article will present an international comparison of investment trusts and analyze the savings orientation of Japanese investment trusts with some discussion of their historical background and policy motivations. Finally, the Article will conclude with some insights into the future of the investment trust both in Japan and in the world.

Due to their expansive growth, Japan's investment trusts at times have been called a new industry. This expansive growth is the result of the dedicated efforts and energy of many people within the securities industry. This growth has been sparked by the gradual relaxation of controls by regulatory authorities and by the unprecedented low interest rates that prevailed in Japan throughout the decade of great liquidity, especially in the $1980 \mathrm{~s}$. Japanese investment trusts have grown from constituting $1.7 \%$ of the financial assets held by individuals in Japan in 1975 to $4.9 \%$ of such assets in $1988 .{ }^{3}$ In comparison, the proportion of all United States household financial assets held in mutual funds has grown from $1.8 \%$ in 1981 to $6.1 \%$ in $1989 .{ }^{4}$

Behind this expansive growth stands the unique history of Japan's investment trust. Japanese investment trusts were developed in response to the poor state of the Japanese economy after World War II and

3. The Bank of Japan (1988).

Financial Assets held by Individuals in Japan (In hundred billions of yen with \% in parentheses)

1. Cash

2. Demand deposits

3. Savings deposits

4. Trust Accounts

5. Insurances

6. Securities

(a) Government bonds

(b) Financial bonds

(c) Stocks

(d) Collective

Investment Trusts

(e) Other securities

7. Others TOTAL

$\frac{1975}{100(6.0)}$
$196(11.8)$
$850(51.1)$
$103(6.2)$
$213(11.9)$
$194(11.7)$
$9(0.5)$
$66(4.0)$
$52(3.1)$
$29(1.7)$
$38(2.3)$
$7(0.4)$
1,663

\begin{tabular}{c}
1985 \\
$202(3.5)$ \\
$358(6.2)$ \\
$2,781(48.0)$ \\
$394(6.8)$ \\
$886(15.3)$ \\
$1,093(18.9)$ \\
$164(2.8)$ \\
$198(3.4)$ \\
$485(8.4)$ \\
$170(2.9)$ \\
$76(1.3)$ \\
$78(1.3)$ \\
\hline 5,792
\end{tabular}

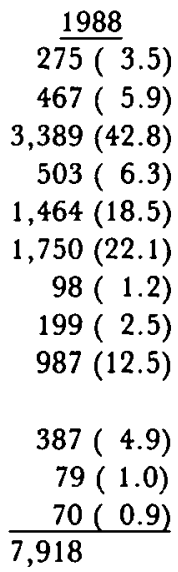

4. U.S. Investment Company Institute, supra note 2, at 64. 
developed as a reasonable response to Japan's changing socioeconomic conditions.

\section{International Comparison of Investment Trust: Congept AND Structure}

The concept and structure of an investment trust are complex. The investment trust is a scheme for collective investment in stocks and bonds by a large number of individuals with small fortunes, offering them the possibility of high returns and capital appreciation without involving large risks, a privilege so far only available to the very rich. ${ }^{5}$ In the United States, the most common form of investment trust is the mutual fund which is defined as follows:

A company that makes investments on behalf of individuals and institutions with similar financial goals. Pooling is the key to mutual fund investing. By pooling (which generates economies of scale) the financial resources of thousands of shareholders - each with a different amount to invest - investors gain access to the expertise of the country's top money managers, wide diversification of ownership in the securities markets, and a variety of services otherwise available only to institutions and wealthy families and individuals. ${ }^{6}$

In the European Community (EC), work has been underway in recent years in the direction of integrating collective investment schemes among its member countries. The adoption of the Minimum Standard for Investment Trust in 1989 by the EC stands as an important milestone in the EC's drive to 1992 and has led the investment trusts modeled on this minimum standard to be called UCITS-type funds. In the EC framework, the investment trust is defined as a form of "undertakings for collective investment in transferable securities of capital raised from the public, and which operates on the principle of risk-spreading, and the units of which are, at the request of their holders, repurchased or redeemed, directly or indirectly, out of those undertakings' assets." ?

5. H. Burton and D.C. Corner, Investment and Unit Trusts in Britain ANd America (1968).

6. U.S. Investment Company Institute, supra note 2, at 14.

7. UCITS-Undertakings for Collective Investment in Transferable Securities, EUROPEAN Community Council Directive (1985). 
This definition hinges on the notion of "open-endedness" so that shares of investors in an investment trust are redeemable or repurchasable at any time at the request of the investors and new fund shares can be offered at any time. United States mutual funds also incorporate this quality of open-endedness. In fact, open-endedness has led United States mutual funds and the EC's UCITS-type funds to be recognized as the international standard for the investment trust concept.

In Japan, the concept of the investment trust is similar to that of the United States and EC concepts with respect to such ideas as the pooling of resources, risk-spreading, and expert asset management. The structure of the Japanese investment trust involves four different parties: the investor (beneficiary), the investment trust management company (sponsor and trustor), the trust bank (trustee), and the securities company.

A securities investment trust is a trust whose purpose is to invest trust funds in specified securities under the direction of a management corporation, with the beneficiary interest sold to the public. An investment trust is created when an investment trust contract is concluded between a management corporation, which makes investment decisions, and a trustee corporation which serves as custodian and performs the necessary bookkeeping functions. The beneficiary interest is divided into equal shares, and investors become beneficiaries by acquiring pro rata shares of the divided beneficiary interests from a securities company. ${ }^{8}$

Securities companies, which originally operate selling of funds' beneficiary certificates under agreements with management companies, play an additionally important role in the Japanese investment trust system by providing such services as the repurchasing of beneficiary certificates and the paying of dividends. ${ }^{9}$

In comparing the British unit trust with the Japanese concept of the investment trust, there are the following differences: (1) instead of defining the investor as a beneficiary as the Japanese law does, the

8. Ichiro Kawamoto, Japanese Securities Regulation 210 (1983).

9. Japan's investment trust is different from a British unit trust and a U.S. mutual fund in a variety of ways. Some of these differences have previously been pointed out by this author in a series of articles on the basic legal structure of Japanese investment trusts which this author has been contributing to Shihon Shijyo, the monthly journal (Japanese version) of the Capital Markets Research Institute of Japan. See also, Noboru Tanabe, Japanese Investment Trust: The Legal Structure and Other Related Issues in International Perspective, Butterworth's Journal of International Banking and FiNancial Law (Feb. - April 1992). 
British law defines the investor as a participant in a collective investment scheme and grants him the status as a party to the trust agreement; (2) in a British unit trust, the experts who are responsible for the management of investments are not called trustor, but are called manager or operator to distinguish them from the investor who is the real trustor; (3) in Japan, the trustee (trust bank) is one of the parties to the trust deed while in Great Britain the trustee of a unit trust participates directly in the collective securities investment scheme; (4) in Japan, securities companies play an important role by providing such services to beneficiaries as the selling and repurchasing of beneficiary certificates and the payment of dividends, even though the securities companies' function is not precisely stipulated by the securities investment trust law; (5) in Great Britain, securities companies can act as underwriters, brokers, or as agents for the unit trust.

In general, investment trusts are comprised of characteristics of both individual and joint trusts, which creates difficulties in the formation of a legal theory and explanation of the structure of the investment trust.

The trust property of an investment trust is constituted of funds raised from investors at large (beneficiaries). The ownership of the trust property passes to the trustee company through the trust deed which is governed by the Securities Investment Trust Law. However, the trust property must be managed separately from that of the trustee bank and eventually reverted to the beneficiaries, and the all-important authority of giving instructions for the investment of trust property is reserved by the management company (trustor). Although the management company is duty-bound to manage the trust property in good faith in ways best suited to enhance the interest of beneficiaries, there is no provision holding it directly accountable to its beneficiaries. What is more, because the ownership (in the bearer form) is not registered with the trustee company and changes frequently from one hand to another, the fiduciary relationship which binds the trustee (including, in effect, the management company) with the beneficiaries is diluted with the passage of time, and this tends to encourage holders of certificates to become interested in annual dividends or any capital gains the investment trust might produce.

As the fiduciary relationship thus becomes diluted, the trust property tends to take on an existence of its own, independently from the trustor, trustee, and beneficiaries. This idea explains why some call trust property 'nobody's property'. ${ }^{10}$

10. See Noboru Tanabe, Shimon Shijyo, Capital Markets Institute of Japan (Dec. 1989). 
The beneficiary certificates of Japan's investment trusts, like those of United States mutual funds and EC UCITS-type funds, can in principle be redeemed at any time as was pointed out by the Investment Trusts Association of Japan. In practice, however, redemption is restricted in many investment trust funds through the inclusion of a closed period. The existence of such a closed period has led these funds to be called "semi-open."

The term "semi-open" can be easily understood through a descriptive analysis. The shares of a "semi-open" investment trust cannot be redeemed for an initial period of time, typically two or three years. However, its shares can be redeemed at any time after the expiration of this closed period, which is why this investment trust is described as "semi-open," rather than just open or closed. The "semi-open" quality of some Japanese investment trusts sets these funds apart from United States mutual funds and the EC UCITS-type funds. ${ }^{11}$

Japanese investment trusts are also classified either as unit-type or as supplementary-funding type, depending on whether or not additional capital can be raised for the investment trust fund after the time of initial subscription. Unit-type and supplementary-funding type investment trusts are themselves classified as either stock investment trusts or bond investment trusts depending on their portfolio structure. A bond investment trust is ordinarily comprised of bonds exclusively. A stock investment trust can contain both stocks and bonds.

At present, the majority of Japanese stock funds are offered as unit-type investment trusts with these funds being the mainstay of the Japanese investment trust industry. Since they do not replenish their capital through additional share offerings and since they restrict early redemption of beneficiary certificates, Japanese unit-type stock investment trust funds cannot be bought and sold with the same ease as can United States mutual funds and the EC's UCITS-type funds.

Investment trusts ordinarily take one of two legal forms: the contract-type or corporate-type. Other legal forms such as the partnership-

11. Internationally, "open-end" refers to an investment trust which offers redeemable securities or which continuously redeems its securities/certificates and, as described in the body, is normally applied to mutual funds in the United States and the UCITS-type funds in the EC. This definition helps to explain why the term "semiopen" is used to describe those Japanese investment trusts with closed periods.

A small number of United States closed-end funds are now making periodical tender offers for their shares with this activity typically taking place on a quarterly basis. Functionally, these funds might be viewed as resembling a Japanese "semiopen" trust. 
type also exist. Only contract-type investment trusts exist in Japan today while company or corporate-type investment trusts dominate the United States investment trust industry. In the EC, the investment trust integration program (UCITS) has provisions for both contracttype funds (FCP - fonds commun de placement) and corporate-type funds (SICAV - societe d'investissement a capital variable). ${ }^{12}$ Therefore, some of the differences between Japanese investment trusts and United States mutual funds are due to the difference in legal form. Both types of trusts can serve similar financial purposes and functions. The segmentation of the trusts into contract-type and corporate-type reflects choices made at different times and in different countries under specific social and economic conditions. ${ }^{13}$

12.

1. Contract-Type

(a) Flexible Type

(b) Fixed Type

II. Corporate-Type

(a) Closed-end

(b) Open-end
Categories of Investment Trust (b) Fixed type

(1) Unit trust (open-end type) in the U.K. and European Community

(2) All unit type and open-end type in Japan's investment trust system

(1) U.K. unit trust at a stage in its historical development

(2) U.S. unit trust at a stage in its historical development

(a) Closed-end

(b) Open-end

(1) U.K. investment trust (mostly for institutional investors)

(2) Some investment companies in the U.S.

(1) U.K. and EC investment companies

(2) U.S. mutual funds

Fixed and flexible refers to the amount of discretion given to the trust's management to change the composition of securities held in the trust's portfolio. Managers of fixed type trusts cannot in their own discretion change the kinds of securities held in the fund's portfolio whereas in a flexible trust managers have complete discretion to make such changes.

13. The goal is to secure the best possible performance in the functioning of collective securities investment with the best possible protection for small investors. In Great Britain, where collective securities investment has a history of over 100 years, the contract-type trust was the norm in the early years. Corporate-type funds were later introduced in relation to the idea that investment trusts should be governed by the Company Act. In the United States, there was a period in the early 1900 s when a variety of investment funds flourished. However, in 1929, when the Great Depression struck the stock market, speculative managements were exposed in some investment companies and many of these companies' clients experienced serious financial losses. Within a few years, these events led to the enactment of the Investment Company Act of 1940, which is the main piece of legislation governing the U.S. mutual funds 
In Japan, debate over the introduction of corporate-type funds has not been exhausted, however. During times of major growth or downward kinds of investment trusts, study has often resumed in preparation for the introduction of corporate-type funds. Today a new focus on this subject is being called for with a view towards further improving the stability of fund management (for example, introduction of closedend corporate-type funds) and harmonizing the Japanese system with its foreign counterparts in order to broaden the path towards crossborder marketing, distribution, and investment (e.g., introduction of open-end corporate-type funds). ${ }^{14}$

The following issues which are presently being discussed in the United States will, however, need to be examined as Japan considers introducing a corporate-type investment trust:

industry to date.

In Japan, just before the outbreak of the Pacific War in 1941, a contract-type investment trust came to exist in the form of a specified money trust. This specified money trust provided Japan with experience in collective securities investment. After the war, collective securities investment was considered again and a draft of a Securities Investment Company Law was prepared. This draft provided for the creation of corporate-type funds in Japan. In 1948, the draft was abandoned as "premature" because of the still turbulent post-war economy, a weak securities market, and the inexperience of the public with direct securities market participation. In its place, the Securities Investment Trust Law was passed in 1951 as a form of special legislation which did not provide for corporate-type funds.

14. The Report of the Study Group on Investment Trusts of the Ministry of Finance states in its discussion of corporate-type investment trusts:

$[\mathrm{T}]$ he corporate-type investment trust is a scheme of collective securities investment through a company established for that purpose, selling its shares to the investing public and distributing asset management income to them in the form of dividends. It features no limit on the management period and no reduction in fund assets, particularly in the case of closedend funds. These factors enable long-term stable asset management. In this sense, the corporate-type investment trust differs in its basic concept from the current investment trust and, thus, requires solution of many problems including extensive amendment of the relevant laws, if it is to be introduced into the Japanese market. For this reason, opinions were expressed that its immediate introduction would not merit the heavy costs envisaged in the process. Nonetheless, the corporate-type is the most popular category of investment trusts. And from the viewpoint of promoting mutual crossborder marketing and sale of investment trusts, corporate-type funds should be worthy of examination for possible future introduction.

Report of the Study Group on Investment Trusts of the Ministry of Finance 8 (May 1988) [hereinafter Ministry of Finance]. 
(i) With regards to open-end investment companies in the United States, it has long been argued that voting shareholders and directors are redundant and, therefore, will hinder the competitiveness of United States mutual funds in the world market. This argument has led to the possibility of the introduction of an alternative pooled vehicle called a Unitary Investment Fund (UIF). The UIF does not have either voting shareholders or a board of directors and can be described as a contracttype investment trust. The United States Securities and Exchange Commission (SEC) has described the UIF in detail in its "Request for Comments on the Reform of the Regulation of Investment Companies." 15

(ii) United States closed-end investment companies have no limit on the length of the management period and allow no reduction in fund assets. Both factors enable them to seek long-term stable asset management. At present, some closed-end investment companies are making periodic public offers for their shares. There is discussion in the SEC's request mentioned above of allowing closed-end companies to provide a redemption-like mechanism. ${ }^{16}$

(iii) In recent years, taxation on income retained at the qualified fund level under Subchapter $M$ of the United States Internal Revenue Code has been strictly reformed.

Under Subchapter $M$ of the Internal Revenue Code, [q]ualified funds pay no federal income tax on their earnings and capital gains which are distributed to shareholders. In order to qualify, a mutual fund has to distribute at least $90 \%$ of its investment company taxable income to its shareholders each year, among other requirements ... [However] the Tax Reform Act of 1986 and subsequent legislation require that a fund distribute $97 \%$ of its income from dividends and interest, and $98 \%$ of its net realized capital gains with respect to the calendar year in which they are earned or realized. The 1986 act also required shareholders to be taxed on their share of a fund's gross income (income before fund expenses are subtracted), rather than on net distributions. This change would have imposed a tax on the 'phantom income' imputed to shareholders, that is, income that shareholders never received but for which they were held accountable on their tax returns.

15. 55 Fed. Reg. 25322 (1990).

16. Id. 
However, this provision was amended in December 1989, before it was ever implemented, to permanently exempt almost all funds. ${ }^{17}$

Two other axes upon which investment trusts can be compared are the scope of eligible investments allowed and the scope of information disclosure required by regulatory provisions. ${ }^{18}$ Great Britain, with its many decades of experience with unit trusts, recently enacted the Financial Services Act of 1986. This new law broadens the scope of eligible instruments for collective securities investment schemes, permitting the purchase of risky commodity products, real estate, futures, and options in addition to conventional securities market instruments.

Unit trusts are at present over-regulated in some respects. The reforms set out below are intended to enhance the range of schemes available without doing away with essential safeguards. This will also enable arrangements of a more speculative character to be offered legally to those investors who have appropriate financial resources and experience . . . With a wider variety of investment opportunities on offer it will be particularly important for the potential investor to appreciate the nature of the investment which he is being offered and the degree of risk involved. The Government proposes that public offers of unit trusts should be made on the basis of a prospectus, as are public offers of shares in a company. ${ }^{19}$

The Investment Company Act of 1940 provides the regulatory framework in which United States investment companies must operate. The Act allows investment companies to offer investment vehicles with varying degrees of risk, ranging from the very low risk money market funds to such high risk ventures as junk bond funds. Investment companies are required to provide fairly detailed information to the Securities and Exchange Commission. Various provisions of the Investment Company Act are designed to ensure the proper exercise of companies' fiduciary duties and to detect any conflicts of interest and self-dealing on the part of companies. The "Investment Company Act is the most complex of the entire SEC series' ${ }^{20}$ of regulation.

17. U.S. Investment Company Institute, supra note 2 at 41-42.

18. One other considerable axis upon which investment trusts can be compared is the method of taxation of investment trusts. This subject will be discussed in a later section of this article.

19. U.K. Department of Trade and Industry, Financial Services in the United Kingdom - A New Framework for Investor Protection, 25 (Jan. 1985).

20. Louis Loss \& Joel Seligman, Securities Regulation 263-264 (1989). 
In the EC, the new UCITS Directive adopts a philosophy that appears fairly progressive and innovative to many. The EC's Directive provides for controls on the legal structure, administration, investment policy, disclosure, and marketing of investment trusts, so as to protect the trusts' participants from excessively risky investments and imprudent management. These provisions seem to reflect the experience of the EC's member countries with the investment trust and other securities related businesses.

The Japanese Securities Investment Trust Law does not contain as many eligible investments in comparison with the British scheme and does not contain the same detailed disclosure requirements as the United States scheme. However, the Securities Investment Trust Law does contain many regulatory provisions designed to protect the investing public in a manner similar to the EC's scheme.

In terms of investment scope, Japanese investment trusts are limited to certain kinds of securities. Investment in short-term financial products such as commercial paper, certificates of deposit, and call loans is allowed only as a temporary haven for their cash position. In fact, the mainstay investment trust is designed as a financial product with low risk and strong savings orientation. In terms of disclosure requirements, the Securities and Exchange Law states in general that no public offering of any security may be made unless the issuer of the security files a registration statement with the Ministry of Finance which fully discloses important information about the security being issued. No sales of the security are, in fact, allowed until the registration statement becomes effective.

The provisions of the Securities and Exchange Law do not, at present, apply to investment trusts. ${ }^{21}$ Instead, the Securities Investment Trust Law stipulates that the management companies must prepare an explanatory statement to be given out by securities companies to prospective certificate subscribers. The companies must also prepare a financial report on the trust fund to be given to each certificate holder at the end of each fiscal year. In addition, the Securities Investment Trust Law provides for the self-regulation of trust structures and management companies' activities by the Investment Trusts Association. The Ministry of Finance plays an important role in protecting the interest of certificate holders by requiring advance approval of each trust deed which covers all matters related to management, sales load,

21. IChiro KaWAMOTo, supra note 8 , at 221. 
redemption periods, and other qualities of newly-established investment trusts. The description should indicate that the Japanese scheme with regard to disclosure policies and investment restrictions is uniquely Japanese in many respects. ${ }^{22}$

The comparison of the scope of eligible investments and the scope of information disclosure in various countries' investment trust systems provides some insight into the ways in which financial order is maintained and viewed in countries such as the United States and Japan. In the United States, judging and anticipating degrees of risk and volatility contained within any collective investment scheme are the investors' business and no one else's as long as the regulatory requirements prescribed for mutual funds are fully met. Almost every aspect of participation in a mutual fund is left to the judgment and choice of investors who may have quite different backgrounds. Investors are solely responsible for such decisions and must accept their results as a matter of course. As a logical consequence, this system requires accurate and adequate disclosure of the contents of the products which are offered for selection to the investors. Any mistake or fraud in the disclosure process is to be prosecuted and punished severely. Financial order of United States markets is usually described as being controlled by market forces. These market forces can have a destabilizing effect on financial order even though investors are well aware of the risks involved in their investments.

22. In Shihon Shijyo, this author describes the legal structure of Japanese investment trusts and compares their governing law to those of other countries. The Financial Services Act of Great Britain and the UCITS minimum standards of the EC first grasp the whole operation of collective securities investment as a plan or an undertaking and then proceed to systematically establish legal relations among the instruments of investment, the management company, the trustee, and the investors. Within this basic framework, they offer a number of different schemes such as trust contract-type and company-type to accommodate investors' diverse needs. They also clearly establish rights and obligations between the management company and investors as the key components of this type of investment relationship.

It is often pointed out, by contrast, that the Japanese legal system for collective securities investment covers a narrower range of issues, does not provide for the investors' legal position in an explicit manner (vis-a-vis management companies in particular), and needs expansion in its systemic approach to legal relations within this type of joint trust which often transcends the bounds of the legal concepts and theories behind the unitary trust. See Japanese Securities Regulation (1983); Shojihomu Kenkyukai, Amerika to Nihon no Shoken Torihikino, Vols. 1-2 (1975) (for a comparison of securities exchange laws and investment trust legislation between the U.S. and Japan). 
Japan has created an economic system that places great emphasis on the control over financial order. The structure and rules of the Japanese financial and capital markets and the relative credit system are carefully designed with an eye towards preventing company failures and extreme volatility as one of their top priorities. The investment trust constitutes one of the links in the chain of this financial system. It is guarded by preventive and reparative safety-net devices which include licensing, capital adequacy standards, line of business control, execution of audits by the Ministry of Finance, and the unprecedented lender of the last resort facility provided by the Bank of Japan during the securities market collapse of 1965 .

A difference in the approaches of Japan and the United States in maintaining financial order can also be observed through the number of investment trust sponsors operating in each country. In the United States, roughly 300 investment trust sponsors were in operation as of September, 1988, with this number not restricted by any regulatory provision. This latter fact is consistent with the United States philosophy of letting market forces, to a great extent, determine the financial order of its markets. In Japan, the number of investment trust sponsors, who are screened and licensed by the Ministry of Finance using a regulatory scheme similar to one applied to banks and life insurance companies, was twenty as of February $1992 .{ }^{23}$ This small number reflects the high standards which the Ministry of Finance requires a company to meet before it can obtain a license to offer investment trust services. Such examination of differences in approaches towards maintaining financial order should enable the United States and Japan to develop a deeper understanding of their investment trust systems so as to improve the cross-border marketing opportunities between the two countries.

\section{The Japanese Investment Trust and Its Savings Orientation}

The unit-type stock fund is the mainstay in the product lines of the Japanese investment trust industry. ${ }^{24}$ This unit-type stock fund

23. Second International Conference of Investment Fund Associations, Toronto (September, 1988) (for world statistics of the number of management companies involved with collective investment schemes including investment trusts). Great Britain has approximately 180 investment trust sponsors.

24.

Types and Sizes of Japanese Investment Trusts

(Figures are of January 31, 1990 and refer to net asset value of the trusts in billions 
features a design which makes it "easy to buy and sell" and which provides for stable management. Structurally, this fund contains a closed prematurity redemption period which enhances its saving orientation through the stabilization of its capital base and thereby its management. The fund's savings-oriented design is provided for through the uniform provisions of securities investment trust deeds rather than in any provision of the Securities Investment Trust Law. ${ }^{25}$

of yen.)

Investment Trust (Contract-type)

$58,140.5$

I. Unit-type

$40,970.5$

a. Stock investment trust

$36,150.6$

(1) Regular interval/pattern offering type

$9,778.1$

(2) Spot-type

$26,372.5$

b. Bond investment trust

$4,819.9$

(1) Long-term government bond fund

$1,594.2$

(2) Japanese/foreign bond fund

$3,225.7$

II. Supplementary-funding type

$17,170.0$

a. Stock investment trust

$9,235.7$

b. Bond investment fund

$7,934.3$

Of these categories, the mainstay unit-type stock funds, most of the supplementaryfunding type bond funds, and some others (unit-type bond funds) have structures emphasizing a savings orientation. Their combined net asset value is a little less than $80 \%$ of the net asset value of investment trusts in Japan. Investment Trusts AssoCIATION OF JAPAN (1990).

25. After World War II, the Japanese government and other public bodies assumed ownership of company stocks in vast quantities, following the dissolution of the Zaibatsu (family-controlled business groups) and the required payment of capital levies by the very wealthy. The Supreme Commander Allied Powers was urged to distribute these securities to the public in order to help begin the reconstruction of the shattered post-war economy and to promote the democratization of securities. However, the resources needed to absorb the released stocks were not in place. Many large potential investors lost much of their wealth through the reallocation of farmland, heavy capital levies, and the spiralling of inflation. Other individual investors suffered greatly from the drastic redistribution of income which occurred through the reforms of the post-war years. As a consequence, stocks were in excess supply, prices tumbled, and the securities market fell into a prolonged depression. The problem was further exacerbated by a huge pool of new stocks which resulted from the quasi-mandatory capital increases by corporations demanded by the Law concerning Corporate Reconstruction and Rehabilitation.

In order to overcome these problems and to foster investment in securities, securities companies and government authorities agreed in 1951 to adopt the investment trust as a means of coping with this crisis and as a way of promoting "people's capitalism" to support Japan's young democracy. The investment trust was chosen for several reasons. First, the capital market after the war was immature and small. The general public lacked sizable wealth, sufficient knowledge, and the requisite 
To accommodate this preference, the investment trust was designed to:

[S]tart with fixed amounts of capital to enable yield recognition within a certain range like bank deposits, diluting as much as possible price and yield volatility characteristic of any financial product featuring actual return payment. As a result, the new product started as a unit-type stock fund with its characteristics uniformly adopted throughout the industry. They consisted of (i) no ceiling for the ratio of stocks in the portfolio and (ii) fixed round-number par values (starting with 5,000 yen which was later increased to 10,000 yen) in (iii) bearer certificates offered for subscription almost every month for (iv) a relatively short two-year maturity (four to five years at present) with ( $v$ ) a prematurity redemption privilege on the part of investors. But (vi) each fund, once established, was not to accept any additional capital.

In short, the newly launched investment trust was a unique modification fit for easy subscription by investors and for concerted mass sale by investment trust companies. Lying in the path of success of this distinctive system was the tradition of par value stock issues in Japan. Prototypical open-end funds offering initial and additional beneficiary certificates at market value with capital gains potential as their chief inducement could not win acceptance among investors long accustomed to par value stocks which virtually promised dividends at fixed rates and new stock allocations at par value. ${ }^{26}$

Unit-type stock funds were originally offered as packaged uniform financial products close in nature to bank deposits. In fact, these trusts were sold based upon the idea that they were almost like bank deposits with the exception that investors could choose, with the expert assistance of investment trust management companies, those funds whose investment objectives were in line with current investment theme and of great interest to the investors personally.

experience needed for capital market investments. Therefore, the Japanese people favored indirect financial assets, such as bank deposits offering fixed interest rates and guaranteed repayment of principal. To accommodate this preference, the investment trusts were designed to be bank deposit-like, as mentioned in the main body.

26. Japan Securities Research Institute, Nihon no Toshishintaku (InvestMENT Trusts in Japan) (1966). This describes in complete detail the problems which occurred in the evolution of investment trusts after the securities market crisis of 1965 . 
These unit-type stock funds grew from their initial level of 14 billion yen in 1951 to over 718 billion yen in $1961 .{ }^{27}$ However, when the securities market suffered a deep downturn in 1965, these and other investment trusts suffered a vicious cycle of stock price declines, net asset value drops, slow fund sales, higher redemptions, and ultimately, the cashing of portfolio stocks. Inevitable results of this cycle were further declines in stock prices, drastic attrition of the net asset value of trusts, and the forced extension of trust maturities. These maladies caused the securities industry to experience a depression of unprecedented severity. In fact, the Bank of Japan, acting as lender of the last resort, stepped in and provided special direct loans to two large securities companies during this depression. This action by the Bank was an unprecedented one and was undertaken because of the Bank's concern that these companies' failures would create great trouble in Japan's credit system as a whole. ${ }^{28}$

Alarmed by this bitter experience, all unit-type stock funds established after this mini-crisis had a built-in mechanism to further their savings orientation by trust deeds. This mechanism encourages stable asset management as much as possible by: (1) restricting the ratio or stock holdings (typically $70 \%$ ); (ii) prescribing closed periods that typically restrict redemption for the first two to three years of the trust's maturity period (recently, the closed periods have been shortened or changed by introduction of new prematurity redemption charges to discourage redemption before maturity); and, (iii) requiring stock price fluctuation reserves to be set aside from $60 \%$ of the excess of net asset value of the fund over the fund's initial offering price, with this amount being similar in nature to retained earnings and with this amount to be invested in instruments other than stocks. These deeds also (iv) stipulated a maximum percentage up to which stocks of any one company can be bought and (v) set a management company's performance based fees at levels somewhat higher than those for other savings product offering fixed returns. (Recently, this incentive fee system has been changed to one based upon total net asset value of management companies).

The closed periods significantly reduce the liquidity of unit-type stock funds which, once established, accept no additional capital from investors. As mentioned earlier, the most apt categorization of these

27. Investment Trusts association of Japan, Investment Trusts in Japan19904 (1990).

28. 6 The Bank of Japan, Nihon Ginkko Hyakunen-shi, Dai 6-kan (100 YeARS OF THE BANK OF JAPAN) (1986). 
Japanese stock funds is "semi-open." This "semi-open" quality greatly enhances the stability of fund management by helping to maintain the fund's capital base. ${ }^{29}$

Characteristic ( $v$ ), incentive fees constituted a major component of the savings orientation of Japanese investment trusts until the modification. These fees led investors and some observers to assume that Japanese investment trust management companies manage their funds in unique ways, including anticipating returns within a certain range and using techniques similar to portfolio insurance. ${ }^{30}$ Such perceptions are in contrast with the basic concepts underlying collective securities investment schemes such as the unit trust in Great Britain and the mutual fund in the United States. These investment schemes are defined as a tool for individuals to seek volatile capital gains and annual trust income at their own risk, assuming that the appropriate disclosures required by regulatory authorities have been made.

The Japanese are sensitive about the preservation of principal and they favor savings vehicles which offer fixed interest income. To accommodate this investor preference, unit-type stock investment trusts were designed so as to anticipate (or target) returns within a certain range, despite their inherently volatile nature and to achieve as much stability as possible in asset management by establishing closed periods of two to three years. By adopting this philosophy, unit-type stock funds tried to build a "floor" below which their performance would not fall, so as to secure income stability even in the worst market conditions. To this end, they maintained meticulously calculated portfolios in which bonds, because of their stable income gains potential, formed the core. They were then mixed at various ratios with stocks that offered the possibility of variable capital gains.

The savings orientation of unit-type stock funds is even further enhanced by the taxation system. Although Japan's tax treatment may be unique and different from those accorded investment trusts in other countries, it has fairly well matched and served the actual stages of development in Japan's social economy. In general, Japanese investment

29. For example, on Black Monday of 1987 , a substantial portion of the balance of Japan's stock investment trust funds were in their closed periods. Therefore, instead of cashing their stockholdings due to early investor redemption, the trust funds could buy stocks at good bargain prices. In fact, the current consensus is that such behavior was a factor in keeping the Tokyo stock market in relative calm while other markets experienced greater downturns.

30. One such observer was Professor John Matatko of Exeter University of Great Britain. 
trusts funds are not regarded as independent taxable entities; instead, investors are taxed when they receive the payments of distributions (income distributions and capital gains from trades or redemptions) from investment trusts. And those distributions are treated as separate, single dividend income (in the case of stock funds) or interest income (in the case of bond funds) without regard to the sources of original incomes (interest, dividend or capital gains) and without being combined with other incomes. At times, this separate taxation prompts foreign tax experts to ask if Japan's individual income taxation adopts a "scheduler" rather than a global income approach.

In the United States, distributions of incomes derived at investment companies are taxed on investors according to the income source, such as interest, dividend and capital gains, a practice based on the socalled "Conduit Theory." In fact, a mutual fund acts as a piece of conduit linking its shareholders and the securities in its portfolio. " $\mathrm{Mu}$ tual fund shareholders are generally treated as if they directly held the securities in the fund's portfolio" so that "an extra layer of taxation is avoided." 31

As described, Japanese investment trusts are taxed at the investor level rather than the fund level to alleviate any problem of double taxation. ${ }^{32}$ The basic formula for taxation at the investor level is called

31. U.S. InVEStMent Company Institute, supra note 2, at 41 . In order for U.S. mutual funds to be treated as conduits or, more technically, regulated investment companies under Subchapter $M$ of the U.S. Internal Revenue Code, the portfolio of an investment company must be diversified, it must meet certain composition-of-income tests, and not more than $30 \%$ of its gross income can be derived from the sale of securities held for less than three months. In addition, the fund must distribute at least $90 \%$ of its investment company taxable income to its shareholders each year. Failure to adhere to such regulations can result in the fund being treated as a U.S. corporation, thus having to pay federal tax at a rate of $34 \%$. Additionally, the Tax Reform Act of 1986 placed further restraints on funds seeking to be regulated investment companies. In order to avoid imposition of a $4 \%$ federal excise tax, funds must declare to shareholders of record by December 31 of each year $98 \%$ of ordinary income and capital gains. Funds have until the following January 31 st to actually pay the dividend. The purpose of this regulation was to accelerate the timing of income recognition by shareholders of such funds to the year in which dividends are declared. Tax compliance is one of the most difficult areas with which fund management and shareholders have to deal.

32. In Japan, there has been no taxation in principle at the fund level for the following reasons, even though any specific provision concerned is not clearly stipulated in tax laws:

(1) Since investment trust funds are not regarded as independent taxable entities, interest and dividend incomes of these funds are exempted from withholding taxation 
the single income taxation formula. This term seems deceiving since income distributions from stock funds are classified as dividend income while income distributions from bond funds are classified as interest income. Moreover, when the shareholder is an individual instead of a corporation, a single flat withholding tax of $20 \%$ is imposed on trust income distributions whether these distributions emanate from stock or bond funds. ${ }^{33}$

Both approaches, Japanese and American, match the reality of collective securities investment offered in the form of financial products. The American flow-through system reflects the risk assumption of mutual fund investors. The Japanese formula accommodates the actual feelings of investors who are the recipients of dividends while simultaneously meeting the administrative needs of a simplified system of taxation.

As mentioned, under the current tax laws, income distributed from stock investment trusts is classified as dividend income and receives the same tax treatment as interest income. The Special Taxation Measures Law excepts it from ordinary stock dividend income and accords

through prescribed procedures Individual Income Tax Law, Art. 176. (1965).

(2) Since no exemption is accorded to interest and dividends paid on foreign securities, these incomes are recognized for the trust properties in amounts after withholding taxes. The amounts equivalent to income taxes levied in accordance with foreign tax laws are kept on record but off the books of the investment trusts and are deducted from the amounts of withholding taxation under certain conditions at the time of income distribution or redemption of the investment trusts. Individual Income Tax Law. Art. 176, item 2. (1965).

(3) The Law for The Encouragement of Employees' Assets Formation which took effect in October, 1975, established the "System of Employers' Contributions to Employees' Asset Formation" in addition to the "Employees' Assets Formation System," and, under this law, the funds established exclusively for the management of these contributions are taxed as the only exception. The rate is one percent for the Special Corporation Tax and local taxes. This exceptional taxation is explained as an interest charge on arrears. Because these funds are not redeemable and do not distribute any income for seven years, paying income inclusive of investment income to the beneficiaries (employees) only once every seven years, the retention of such unpaid incomes causes long deferrals in taxation.

33. Japan, like the United States and other countries, once adopted the formula of taxation by income source. This formula did not fit well with reality, however. Investors often invest in a variety of fund beneficiary certificates and repeat buy and sell transactions many times during a taxable year. It makes income source identification an extremely complicated process, and the situation can be no less troublesome for the management companies and trustee banks. For this reason, the formula was soon replaced by other methods which have evolved into the current single income taxation formula. 
it a reduced tax rate (15\% income tax and $5 \%$ local tax at present) and separate taxation from other income. While no tax credits are given for dividend income from stock funds in the case of individual taxpayers, corporations enjoy the exclusion of dividend income from gross revenue within a prescribed range.

One reason given for the quasi-interest income treatment of stock fund distributions is that stock funds are today a widely accepted vehicle for small investments. Another reason is to put stock funds on an equal footing with the similarly structured jointly-managed money trust accounts whose income distributions are taxed as interest income. At any rate, the treatment of income distributions (dividend income) from stock funds as if this income was interest on deposits offering fixed rates on fixed amounts of principal is a major characteristic of stock investment trusts in Japan.

The extension in 1977 of the Maruyu privilege, the basic tax exemption for small-lot savings accounts, to stock investment trust funds is said to have marked an epoch in the history of Japan's investment trust system. However, to qualify for this exemption, (i) the fund's objective had to be to secure stable income distributions; (ii) stocks' ratio in the portfolio had to be less than $70 \%$; and (iii) the weight of any one company's shares could not be more than $5 \%$. Stock funds which met these requirements have been the major force in the growth of stock investment trusts and are the mainstay of this category of investment trusts in Japan today. However, the Maruyu tax incentive system was abolished in 1988. A similar tax exemption survives only for certain taxpayers, handicapped persons and senior citizens, under the "Tax Exemption for Senior Citizens' Small Amount Savings" plan. ${ }^{34}$

It may be asked why stock investment trusts have been granted the same favorable treatment regarding taxation as safe and sure savings deposits despite the inherent risk of share price volatility in these stock trusts due to the presence of stocks in their portfolios. In addition to the explanations for taxation of stock fund income distributions as interest income, the following two reasons were offered for the granting of the Maruyu privilege:

(1) From the outset, the stock investment trust has been a scheme for stock investment by experts on behalf of and for the interest of many inexperienced investors who are the

34. Individual Income Tax Law, Art. 10 (1965); Income Tax Law Enforcement Order, Art. 33 (1965); Income Tax Law Enforcement Regulations, Art. 5 (1965). 
beneficiaries in the trust. This characteristic has been accentuated by the increase in the number of small investors who flocked to this type of fund as a result of the introduction of the monthly payment cumulative investment plan. Furthermore, technical sophistication in fund management has advanced in the direction of stability through the introduction of family funds. ${ }^{35}$

(2) Although risk always exists due to stock price volatility, very stable bonds, principal-guaranteed call loans, and certificates of deposits have gradually come to constitute larger and larger shares of the stock funds' portfolios. ${ }^{36}$

Although the Maruyu tax incentive system has been abolished with regard to investment trusts, the savings orientation of unit-type stock funds still exists because of the inclusion of closed periods and the existence of stock price fluctuation reserves. The savings orientation of unit-type stock funds also is maintained through such factors as the licensing of investment trust management companies by the Ministry of Finance and many regulatory provisions.

The savings orientation of Japan's investment trust is not, however, the monopoly of unit-type stock funds. In fact, many bond investment trust funds are comprised of features which function to encourage

35. Family funds were introduced in 1967 by an amendment to the Securities Investment Trust Law for the improvement of efficiency and consistency in asset management. Family funds are expected to accomplish these goals by allowing the unification of assets management for unit-type funds launched each month. Family funds are composed of a few parent (mother) funds and many subsidiary (baby) funds. Within this framework, mother funds are responsible for concentrated investment, and each baby fund invests in principle only in the beneficiary certificates of the mother fund. This scheme was designed to rectify the weakness of unit-type funds, namely, the fund capital attrition created by the early redemption without replenishment by additional beneficiary certificate sales and the resulting erosion in consistency in fund management. Family funds experienced rapid growth beginning in 1970 , but have lost some of their momentum in recent years. This latter fact is due to the reversion by certain funds to independent investment management of each fund which has been stimulated by the phenomenal advances in computer-based asset management control capabilities.

36 .

InVEstment Trusts Association of Japan (1990).

Portfolio Composition of Stock Investment Trusts (\%)

$\begin{array}{lrrrrrr} & \underline{1951} & \underline{1961} & \underline{1971} & \underline{1981} & \underline{1986} & \underline{1989} \\ \text { Call Loans, CDs, etc. } & 9.4 & 10.6 & 28.2 & 23.6 & 20.8 & 31.7 \\ \text { Bonds } & 0.6 & 16.2 & 16.2 & 35.8 & 46.2 & 18.8 \\ \text { Stocks } & 90.0 & 73.2 & 55.6 & 40.6 & 33.0 & 49.5\end{array}$


savings by the Japanese citizenry. Long-term bond investment trust funds were introduced in 1961, ten years later than stock funds, and were the first bond investment trusts in Japan. These bond funds are of the supplementary-funding type, not unit-type. Long-term bond investment trusts operate in a uniquely Japanese way and are different from the typical international open-end bond fund that offers unrestricted purchase and sale opportunities. These long-term bond investment trusts are designed more elaborately than the unit-type stock funds mentioned above and exhibit attributes closer in nature to principalguaranteed savings and deposit accounts. To achieve this latter quality, these funds utilize the characteristic of bonds that assures par value redemption if the bonds are held to maturity and mitigate bond price volatility through a special design which includes the anticipation of returns, the use of a theoretical valuation method, and the adoption of cumulative investment plans.

In practice, these funds are offered for subscription with an anticipated return set for the first year and an assurance of the maintenance of par value through the theoretical valuation of bonds held in their portfolios. In the case of unlisted bonds purchased in large quantities, valuation is on the basis of costs of these unlisted bonds which are normally lower than the par value of the bonds at purchase with unlisted bonds being subsequently valued in a virtually straight upward slanting line to reach par value at redemption.

Shortly after 1961, long-term bond investment trusts suffered a setback due to a rush of purchases by corporate hot money. At that time, the secondary market for bonds still remained undeveloped making recovery a slow process. However, since recovering from this setback, these funds have been sold exclusively to individuals for cumulative investment purposes. Because of their characteristics regarding management and sales, they have been accorded the same tax incentives as those accorded bank deposits even before these incentives were applied to stock investment trusts. Other tax privileges designed to encourage savings have been made available to these bond funds and others without requiring specific qualifications, setting bond funds apart from stock funds. Bond investment in Japan is generally thought to be difficult and unattractive to the individual investor. This may sound strange, given such characteristics of bond investment as long maturities, payment of a fixed amount of interest, and guaranteed return of capital at redemption. However, these plus factors are offset by such minus factors as large units of transactions, the possibility of capital losses if the bonds are cashed before maturity, meticulous attention required in the selection of issues and in regard to notices of redemption, and relatively burdensome administrative chores including the reception and 
redemption of coupon payments. These factors have hampered the use of buying bonds as a means of savings by the general public.

Long-term bond investment trusts have been able to overcome these drawbacks even though their introduction was delayed by ten years mainly because of the immaturity of the bond market. In fact, long-term bond investment trusts opened the way for individuals with small means to invest in public and private bonds. These new instruments of savings have greatly contributed to the formation of diversified asset portfolios held by the general public and have permeated a broad spectrum of the saving populace, this development being aided by the expansion of cumulative investment accounts. ${ }^{37}$

In 1980, medium-term government bond funds were introduced as a new group of supplementary-funding type bond funds. These funds are primarily invested in medium-term government bonds and have a structure featuring a strong savings orientation. These funds also offer various arrangements, such as automatic dividend re-investment and relatively high returns to attract medium-to short-term stable funds.

Sharing many of the features of money market funds (MMF) which triggered a financial revolution in the United States, these funds were welcomed into the Japanese financial market as an epoch-making short-term financial product. Their characteristics are so close to bank

37. In 1975, government bonds began to be issued in massive quantities. To cope with this situation, the Securities Exchange Council of the Ministry of Finance issued "A Recommendation for the Development of the Bond Market" in October, 1977. In this recommendation, the Council emphasized the need for the removal of controls over the bond market and advocated an open market for bonds and the market's expansion both in breadth and depth through effective competition. From this viewpoint, the recommendation called for improvement in the practice of anticipated returns premised on regulated interest rates as well as in artificial aspects such as the structure of the bond based on theoretical valuation. The Council then expressed the hope that new products would be developed on the basis of more flexible pricing reflective of demand and supply forces in the market and more in line with the trend of liberalization based on secondary market values.

Preceding this recommendation, the Investment Trusts Association noted in an opinion paper issued by the Committee for Research on Bond Investment Trusts and entitled "On Bond Investment Trusts, March, 1977" that "bond investment trusts meet investor needs through stable income distributions based on anticipated investment returns" and "the scheme will be sustainable through an emphasis on cumulative investments in fund sales and on the maintenance of liquidity in asset management." The paper concluded that for these reasons the current bond investment trust system should remain unchanged for the time being.

Today, these two positions, one calling for reform and the other calling for stability in the bond investment trust system, remain side by side with old-type longterm bond investment trusts structured on the basis of anticipated returns and theoretical values while new types are based on variable actual returns and market values. 
deposits that they have almost transcended descriptions such as savings orientation and quasi-savings. Offering great liquidity and attractive returns, these funds have a strong competitive edge over rival products of financial institutions whose yields are typically subject to interest rate controls.

The recent introduction of the integrated fund investment account bolsters the competitive edge of medium-term government bond funds. This new account shares many features in common with cash management accounts (CMA) in the United States. It accepts funds through savings accounts opened with many Shinkin Banks for small business (swing service), an arrangement that provides a clearing function for medium-term government bond funds similar to that for savings and deposit accounts. This arrangement enhances the stability and convenience of these funds for the investor. The same effect is also achieved through cooperative ventures between medium-term government bond funds and credit card companies. Therefore, development of the integrated fund investment account represents the advent of a financial service which offers both a clearing function and an investment function in the same package.

Medium-term government bond funds are the largest type of bond investment trusts with approximately five-and-a-half trillion yen in net assets as of January, $1990 .^{38}$ Efforts are required to further increase the attractiveness of this type of investment trust in step with the expanding liberalization of short-term interest rates and the development of the short-term open market which lacks core instruments such as short-term treasury bills, as noted by the joint Special Study Group of the Ministry of Finance and the Bank of Japan.

The savings orientation of bond investment trusts can be examined not only in the supplementary-funding types of funds described above but also in unit-type bond investment trusts. The unit- and spot-type bond fund was introduced in 1974. This fund touts a portfolio comprised of high-yielding bonds purchased in the secondary market and complete

38 .

Types And Sizes of Bond Investment Trusts

(Figures are of January 31, 1990 and refer to net asset value of the trusts in billions of yen)

(1) Long-Term Bond Investment Trusts

(2) Medium-Term Government Bond Funds

5,534

(3) Free Financial Funds

(4) Others 
closure through the entire trust term, qualities designed to draw even more upon the above-mentioned characteristic of bonds that assures par value redemption if held to maturity. ${ }^{39}$ This bond fund relies more upon its product development capability than the asset management expertise of its investment trust management company in terms of its attraction to investors. ${ }^{40}$

The response of Japanese investment trust management companies to this situation has been to offer a wide range of investment products from medium-term government bond funds on the reduced risk side to open-end stock funds which involve elements of price volatility exposure and greater risk exposure. Between these two poles comes the group of unit-type stock funds which today enjoy the greatest popularity and constitute the mainstay of the Japanese investment trust industry.

On the periphery of the mainstay group are funds like the openend convertible bond fund and many supplementary-funding type investment trusts which offer investors dual discretion: the choice of funds

39. When this type of fund was introduced in 1974, high-yielding public and corporate debt instruments were floated in quick succession, reflecting the financial tightening then underway. In the secondary market, bonds were traded in very large units since an overwhelming majority of bonds placed in circulation were held by financial institutions and were traded mainly among institutional investors. As a result, individuals with small amounts of money to invest had reduced access to high-yielding bonds. Under these circumstances, the development of the unit- and spot-type bond fund ideally fit the needs of small investors. Complete closure through the entire trust term restricts turnover in its portfolio while encouraging the maintenance of a strong savings orientation with attractive yields.

40. Investment Trusts Association of Japan, Shoken Toshi-shintaku Sanjyu-Go-nen Shi (The Thirty-five Year History of Investment Trusts) (1987).

The development of Japanese investment trusts reflects responses to a great variety of specific socioeconomic events at varying stages in the reconstruction and growth of post-war Japan. Among the many factors which have affected the development of the investment trust industry, one of the more prominent is investment risk preference of the individual Japanese investor. Individual investors in Japan are made up of many different types. Some emphasize capital risk avoidance, stable asset management, and uninterrupted income distribution. Others are drawn to active management for capital gains purposes, while opt for a combination of the two.

In the United States, some individual investors also emphasize preservation of investment capital. This emphasis on preservation of capital has become more pronounced in the U.S. after the stock market collapse of Black Monday of 1987. For example, some long-term variable mutual funds are now trying to accommodate client's growing emphasis on stability by making their performance more predictable and stable even at the cost of somewhat larger expenses and lower returns. These funds are doing this by taking out special insurance policies and getting bank guarantees on bond yields and on the performance of options held in fund portfolios. 
exhibiting or promising superior performances and the choice of timing to buy or sell. However, savings-oriented funds still constitute a high percentage of the total amount of funds. This fact raises the question of whether the present composition of investment trusts is the result of uniform trust characteristics, investors' motivation, marketing and subscription activities of securities companies, or a combination of these three factors and others. The answer to this question is not an easy one, but as this Article suggests, all these factors have greatly affected the development of investment trusts in Japan in one way or another.

\section{Investment Trust: Current Outlook and Future Prospects}

Today in Japan, investors should be completely free as a matter of principle in a market economy to choose their financial products or the services of intermediaries. Their choices should ultimately depend not only on their objectives for savings and investment but also on the quantity as well as quality of information they have about financial markets and financial products. This statement in support of investor selection freedom would have been unthinkable both during the years immediately before and after the introduction of the investment trust which took place after the end of World War II and during the years immediately following the securities market depression of 1965.

Today, however, the financial landscape has changed with the Japanese domestic markets growing and maturing each year while at the same time Japanese investors continue to mature. Behind these domestic changes stands the process of the internationalization of securities markets and all the effects which this process creates. Together, the domestic and international changes reflect the need for reexamining in detail the current Japanese investment trust system.

Other countries have responded to these changes in a manner similar to the one called for in this Article. For example, the United States' SEC has recently announced that it is considering revising the Investment Company Act of 1940 so that the Act will better reflect the changed market environment, which includes the internationalization of securities markets. The SEC "seeks comments on how to best facilitate competition between United States investment companies and advisers and foreign investment companies and advisers, both domestically and abroad." ${ }_{41}$ Great Britain, through its Financial Services

41. Supra note 15. This request is part of a program in which a study group established by the SEC will undertake a comprehensive review of the American mutual 
Act of 1986, introduced new forms of investor protection and an openend style investment company which had been studied for many years before its introduction. In the EC, a move is afoot to liberalize crossborder marketing of investment trusts through the EC's UCITS Directive.

Such developments within other countries and Japan should provide Japanese investment trusts with a stimulus to pursue reforms and changes that will enable them to become more viable and competitive in this rapidly changing world. In other words, these changes raise questions about how each country's investment trust system must develop in order to achieve an appropriate level of international acceptability. Today, this process of adjustment has already begun and will continue for many years to come. In fact, foreign-owned investment trust management companies were recently allowed into the Japanese market. ${ }^{42}$ Their entrance and operation will mark the opening of a new era for the investment trust in Japan. Such foreign investment trust management companies which have been onlookers from the outside may once inside be even more puzzled by the uniqueness of Japan's investment trust system.

Japan's investment trusts are broadly divided into the savingsoriented mainstay products of the unit-type stock funds versus all other funds. The unit-type stock funds clearly exhibit insularity in the restriction they place on liquidity through their prohibiting or discouraging trust deeds of prematurity redemption, the semi-open quality of these funds. Does this imply that, as far as Japan is concerned, internationalization or cross-border marketing of investment trusts are to be limited to the narrow area of non-mainstay products? Similarly, since Japanese citizens prefer those investment trusts which feature a savings orientation based on stable returns, any attempt by a non-Japanese investment trust management company to offer investment trusts in Japan without these characteristics may prove futile. ${ }^{43}$

fund system. This review will focus on how to expedite cross-border marketing and sales of investment trusts and will examine the possibility of the introduction of contracttype investment trusts into the U.S. SEC Chairman Richard Breeden's Address to the General Meeting of the U.S. Investment Company Institute (May 10, 1990).

42. Report by the Study Group on Investment Trusts, Securities Bureau of THE Ministry of Finance (1988). As of January, 1992, four foreign-affiliated financial companies have been approved to get a license to establish investment trust management companies.

43. Nihon Keizai Shinbun, The Japan Economic Journal (May 5, 1990) (Merrill Lynch reportedly sounding out the Ministry of Finance on the possibility of marketing in Japan a dollar-denominated MMF, a popular saving vehicle in the U.S.). 
The non-mainstay products of the Japanese investment trust system are of the open-end type which is widely accepted internationally and which allows the purchase and sale of beneficiary certificates at any time. Thus, the greatest opportunity for international capital flows through or the largest growth potential for Japanese investment trusts might be found in the narrow world of non-mainstay instruments. Does this imply that a large unexplored territory remains before any future cross-border advances can be made by Japanese investment trusts?

Japan's unit-type stock funds are a mass market savings product incorporating many useful ideas and mechanisms. Even though these funds do not provide any legal protection to investors with regard to the preservation of fund capital, they do manifest great efforts for stable investment and initiative through the actions of their management companies as financial intermediaries. On the other hand, stock funds of the supplementary-funding type which are premised on the investors' own responsibility for risk emphasize disclosure commensurate with their inherently risky nature. From an international perspective, both of these types of funds have ample room for refinement. Refinement concerns the basic posture of Japan's investment trusts as to investor protection (particularly, disclosure requirements), the fiduciary duty owed by management companies to investors, and an adequate safety net surrounding investment trusts. The question remains as to how in the future should Japanese investment trusts refine these various elements.

Investment trusts supply funds to the real sector of the domestic economy as well as the international economy through the purchases of primary securities. This function should be continued and expanded in our rapidly changing world where drastic changes have been called for in Japan's domestic economy (i.e., increased public spending and increase in number of imports) and where major recycling of Japanese capital has been called for vis-a-vis the rest of the world. In fact, concerns are being voiced about a shortage of savings on a global scale, and, in this context, Japan is expected to make contributions to the supply of funds available to the poorest and most heavily indebted countries, newly developing countries, and the reforming economies of Eastern Europe. ${ }^{44}$

There is a question as to which direction the mainstay unit-type stock funds and the non-mainstay stock funds of the supplementaryfunding type and all types of bond funds should be developed. The question may be answered by looking to the Foreign \& Colonial Gov-

44. International Monetary Fund, World Economic Outlook (May 1990). 
ernment Trust which was launched more than a century ago in Great Britain. This trust offered a fixed long-term yield, and was viewed as the pioneer of investment trusts. Country funds, which generally take shape as closed-end investment companies with their shares listed on stock exchanges, such as New York (for example, the Korean Fund which enjoyed a strong boom for some years in the United States), or as contract-type investment trusts (for example, the Spain Fund which was developed in Japan) provide other possible forms which investment trusts could take in order to address these important issues.

Some might say that we have come to a stage in history where developing and implementing effective programs for the recycling of capital accumulated in Japan to foreign countries requires investment trusts to simultaneously play new roles: specifically, to develop stronger savings orientations and to fine-tune their impact on the capital flows both inside and outside the securities markets of the recipient nations.

The questions raised above provide a brief look into the future of the Japanese investment trust system. These questions are not simple and will have to be examined with close scrutiny for some period of time. One study has been undertaken by the Study Group on Investment Trusts, Securities Bureau of the Ministry of Finance. This group recently released a report which stated:

Reform efforts should not be limited to the international harmonization of investment trusts but should rather embrace a more down-to-earth reflection of the current system from a broader perspective focusing on how to accommodate mass investors' diverse needs and build an environment which will enable selections on their own initiative. ${ }^{45}$

In specific terms, the Report provides guidelines applicable on such subjects as: (i) diversification of product characteristics and maintenance of stable management (e.g., introduction of prematurity redemption charges to discourage massive redemptions often seen immediately following the end of a closed period); (ii) increase in the number of eligible investment products and relaxation of control over the investment of the trust's cash position; (iii) more thorough overall disclosure and comparison of performance; (iv) stronger independence of (or fulfillment of fiduciary duty by) management companies; ( $v$ improvement in the rules for the marketing of foreign investment trusts in Japan; (vi)

45. Report of the Study Group on Investment Trusts, 5 (1988). 
reform of the current Securities Investment Trust Law; ${ }^{46}$ and (vii) issues concerning new entries into the investment trust market. ${ }^{47}$

The utility of any guidelines or answers to the questions asked will depend to a large extent upon the views of those who are concerned with the future of the Japanese investment trust industry. Such views may provide the best insight into how the investment trust system must develop and change. ${ }^{48}$

46. The Report's guidelines for the reform of the Securities Investment Trust Law require specific improvements in disclosure such as securities companies' obligations to provide explanatory statements to prospective certificate subscribers and investment trust management companies' responsibility for damage compensations for misrepresentations and their obligations to file explanatory statements with the Minister of Finance for review (including the Minister's power to order corrections). The Report demands that disclosure be made on levels similar as to those provided for in the Securities Exchange Law.

47. On March 9, 1990, the Investment Trusts Association released an opinion paper entitled "On the Improvements of the Investment Trust System." This paper represented an action program in pursuance of the recommendations proposed in a paper entitled "On the Future Course of Investment Trusts" which was issued in May, 1989, by the Study Group on Investment Trusts, Securities Bureau of the Ministry of Finance. The main part of the Investment Trusts Association's paper concerned the mainstay unit-type stock investment trust funds and proposed: (1) diversification of product orientations; (2) diversification of subscription fees and trust fees; (3) measures for the stabilization of asset management, including revival of withdrawal charges and leveraged asset management: and (4) expansion of disclosure regarding fund structures and performances.

48. Japan's investment trusts have come to a stage where the traditional Japanese paradigm should be transcended for further growth and development. They are very unique by international standards and so need basic reform in many respects to be accepted as internationally viable financial products. The present system is the product of many years of development. As such, it suits the purposes fairly well with no particular complaints lodged from investors. In this sense, reform may not be an urgent necessity. Nevertheless, since no financial products without universal compatibility can be expected to attain a meaningful position in the days ahead, these basic problems must be addressed seriously from every conceivable angle.

TOSHIYasu Asao, former chairman of the Investment Trusts Association of Japan (Interview for a special column on the announcement by the Ministry of Finance on the problem of new entry into the investment trust market), THE REPORT OF THE Study Group on Investment Trusts, Kinyu Zaisei Jijo (June 19, 1989). 